\title{
Hydrochemical and Isotopic Investigation of the Groundwater from Wajid Aquifer in Wadi Al-Dawasir, Southern Saudi Arabia
}

\author{
Mohammed Benaafi ${ }^{1, *}$ and Abdulaziz Al-Shaibani ${ }^{2}$ (D) \\ 1 Interdisciplinary Research Center for Membranes and Water Security, King Fahd University of Petroleum \& \\ Minerals, Dhahran 34464, Saudi Arabia \\ 2 Ministry of Environment, Water, and Agriculture, Riyadh 11195, Saudi Arabia; shaibani@kfupm.edu.sa \\ * Correspondence: benaafi@kfupm.edu.sa
}

Citation: Benaafi, M.; Al-Shaibani, A. Hydrochemical and Isotopic Investigation of the Groundwater from Wajid Aquifer in Wadi Al-Dawasir, Southern Saudi Arabia. Water 2021, 13, 1855. https:// doi.org/10.3390/w13131855

Academic Editor:

Alexander Yakirevich

Received: 18 May 2021

Accepted: 24 June 2021

Published: 3 July 2021

Publisher's Note: MDPI stays neutra with regard to jurisdictional claims in published maps and institutional affiliations.

Copyright: (c) 2021 by the authors. Licensee MDPI, Basel, Switzerland. This article is an open access article distributed under the terms and conditions of the Creative Commons Attribution (CC BY) license (https:// creativecommons.org/licenses/by/ $4.0 /)$
Abstract: The Wajid aquifer is considered the main source of water for drinking and irrigation in Wadi Al-Dawasir and Najran, the southern region of Saudi Arabia. This aquifer has been used since the 1960s, and due to the expansion in agricultural activities, the aquifer has been overexploited. The study aims to understand the origin, hydrochemical processes of the groundwater in the shallow unconfined, deep unconfined, and confined parts of the Wajid aquifer in the Wadi Al-Dawasir area. In-situ hydrochemical parameters ( $\mathrm{pH}$, temperature, EC, and TDS) were measured in the field, and groundwater samples were collected for major ions and stable isotopes $\left({ }^{2} \mathrm{H}\right.$ and $\left.{ }^{18} \mathrm{O}\right)$ measurements in the laboratory. The results show that the groundwater in shallow unconfined, and confined aquifers are of two types; $\mathrm{Cl}_{2} \mathrm{SO}_{4}-\mathrm{Ca}$. Na and $\mathrm{Cl}_{\mathrm{SO}}-\mathrm{Na}$. Ca; however, groundwater in deep, unconfined aquifers is characterized as $\mathrm{HCO}_{3}-\mathrm{Ca} . \mathrm{Na}$, and $\mathrm{Cl} . \mathrm{HCO}_{3}-\mathrm{Ca}$. Na; types of groundwater. The isotopic analysis results reveal that all groundwater samples have values of $\delta^{18}$ Oand $\delta^{2}$ Hclose to the local and global meteoric water lines, indicating the meteoric origin of Wajid groundwater. Three major hydrochemical processes, including rock weathering, ion exchange, and evaporation, have been identified as key controls on the chemical composition of water in the studied aquifer. The evaporation and ion exchange processes have more influence on the chemical composition of groundwater in the shallow unconfined and confined aquifers. On the contrary, weathering of carbonate minerals affected more the chemistry of groundwater in a deep unconfined aquifer. The unconfined section of the Wajid aquifer shows a reverse pattern of salinity with higher salinity in the recharge area, which is most probably related to the return irrigation water and leaching of salty soil. The open fractures in the upper part of Wajid sandstone most likely act as conduits to percolated saline water to the Wajid aquifer.

Keywords: Saudi Arabia; Wajid aquifer; isotope; hydrochemical processes; groundwater origin

\section{Introduction}

The area of this study is located in the southern part of Saudi Arabia, in the Wadi Al-Dawasir (Figure 1), where the groundwater from the Wajid aquifer is the main source of water for drinking and irrigation purposes. The agricultural activity in Wadi Al-Dawasir expanded since the 1960s, and water demand for irrigation increased [1]. As shown in Figure 2, the crop area in Wadi Al-Dawasir increased from less than 5\% (1973) to 15\% (1984) and to $41 \%$ (2018). This increase in crop area is associated with increases in water demand for irrigation, which is only satisfied by groundwater from the Wajid aquifer and led to aquifer overexploitation. Understanding the hydrochemical evolution of Wajid groundwater by delineating its hydrochemical characteristics and isotopic composition is essential for sustainable groundwater development. The hydrochemical characteristics of groundwater are usually affected by the chemistry of recharge water and the hydrochemical processes along the groundwater flow paths [2]. An integrated approach to analyze the hydrochemical and isotopic data was adapted to identify the origin and hydrochemical evolution of the studied groundwater. 


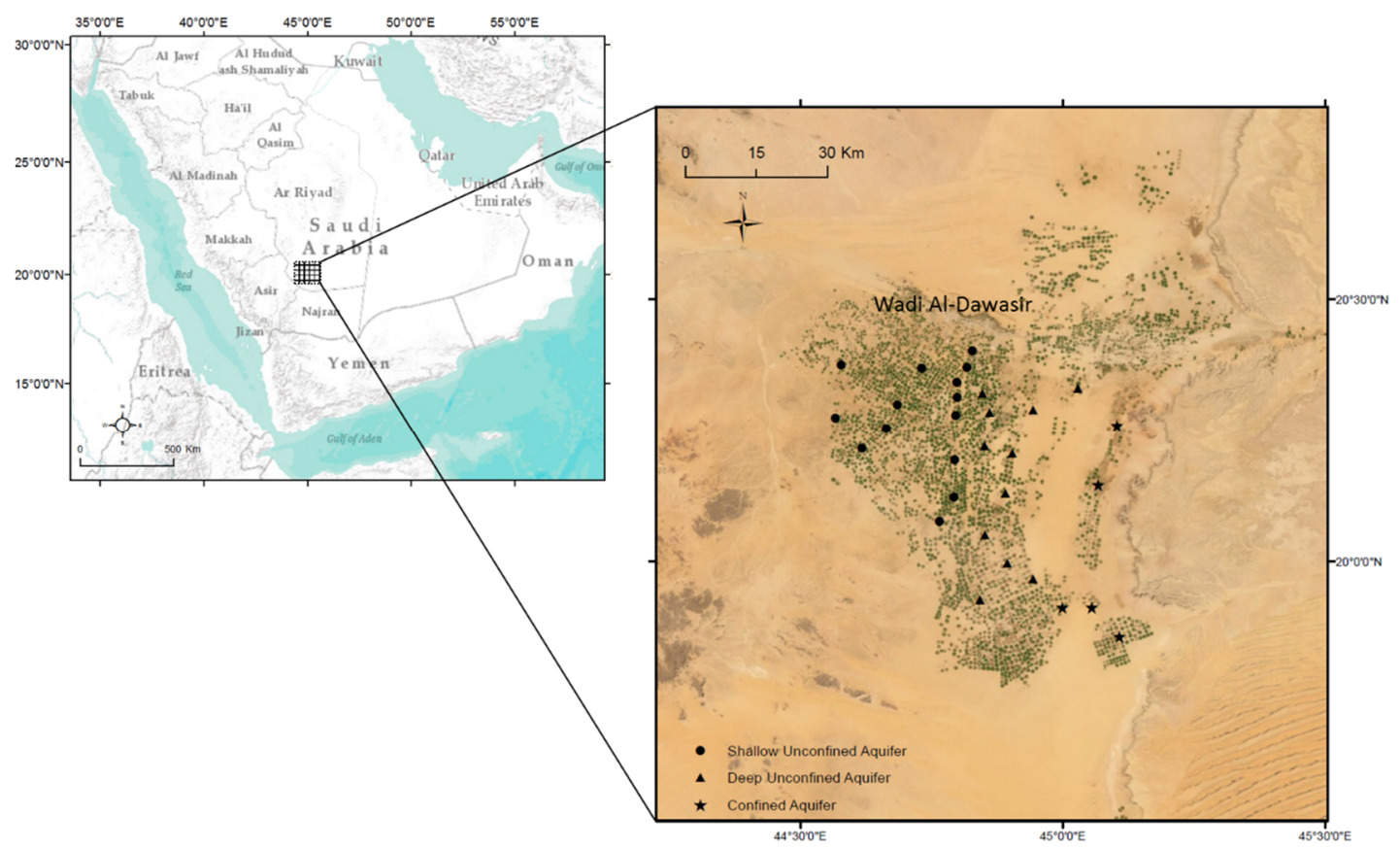

Figure 1. Location map shows the groundwater samples from unconfined and confined parts of the Wajid aquifer in Wadi Al-Dasawir, southern Saudi Arabia.

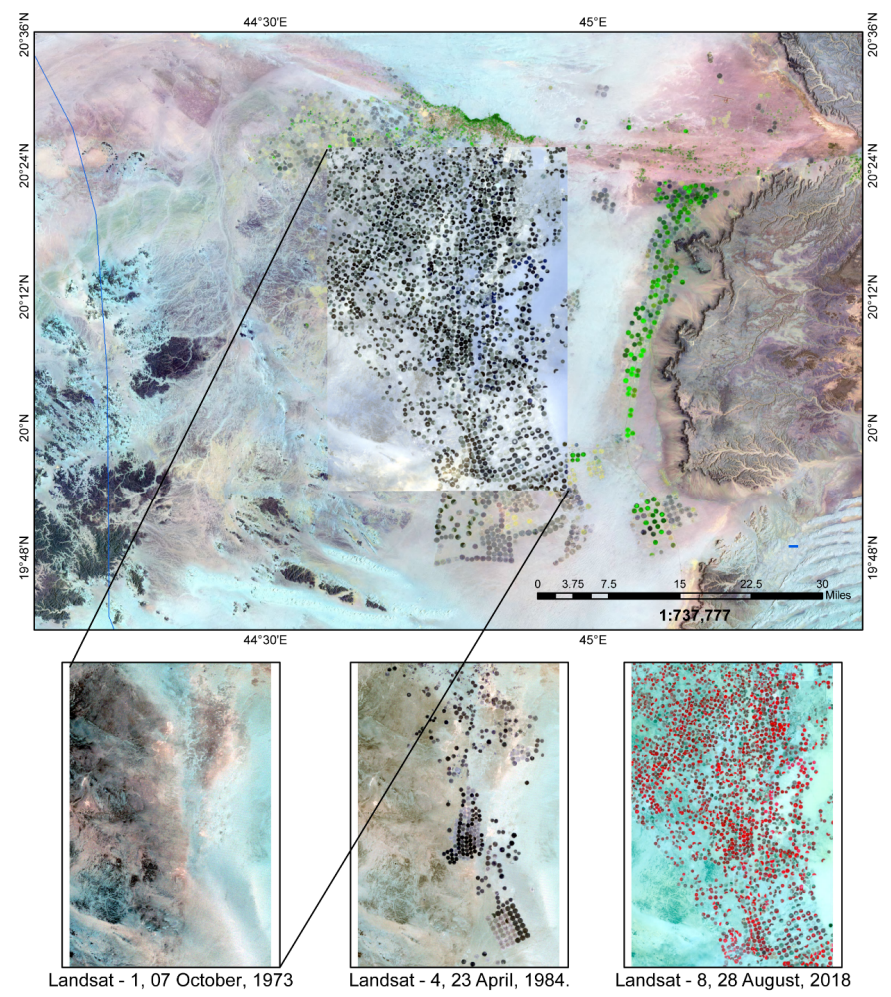

Figure 2. Time-series Landsat satellite images show the temporal change in agricultural activities in the Wadi Al-Dawasir area in the period from 1973 to 2018.

Wajid aquifer formed within Cambro-Permian sandstone succession, which consists of fine to very coarse sandstones that deposited in a variety of depositional environments of fluvial, shallow marine, and glacial-fluvial ones [3,4]. Wajid aquifer is a regional and fossil aquifer, which is under the unconfined condition in the outcrop area (western part of the study area), and confined ones in the subcrop area (eastern part of the study area) Figure 3. At a regional scale, the aquifer display thickness ranging from 200 to $900 \mathrm{~m}$ over an area 
of about $170,000 \mathrm{~km}^{2}$ [5]. The groundwater is fossil and non-renewable with residence time greater than 30,000 years $[1,6]$. The Wajid aquifer is a single aquifer in the shallow subsurface (area of this study); however, in the deep subsurface (east of the study area), it is subdivided into lower Wajid aquifer and upper Wajid aquifers that are separated by a thick shale layer [1]. The hydraulic properties of the Wajid aquifer are spatially varied due to the variability in the density of open fractures, which have significant control over them [7]. Its hydraulic conductivity was reported in the range from $4.6 \times 10^{-5}$ to $1.9 \times 10^{-4} \mathrm{~m} / \mathrm{s}$ [1]. The groundwater flow in the studied aquifers illustrated in the water level contour map, as shown in Figure 4. It flows toward the northeast with a gradient of 0.002 . The recharge area is located south and southeast of the study area.

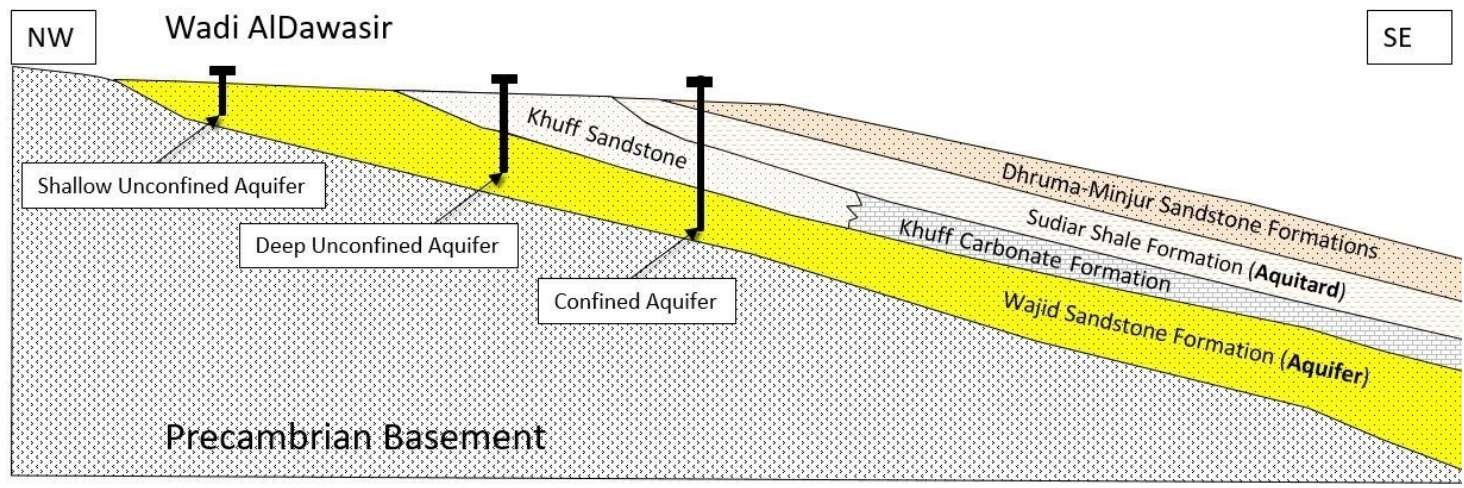

Figure 3. Hydrogeological cross-section of Wajid aquifer showing the hydrostratigraphic units.

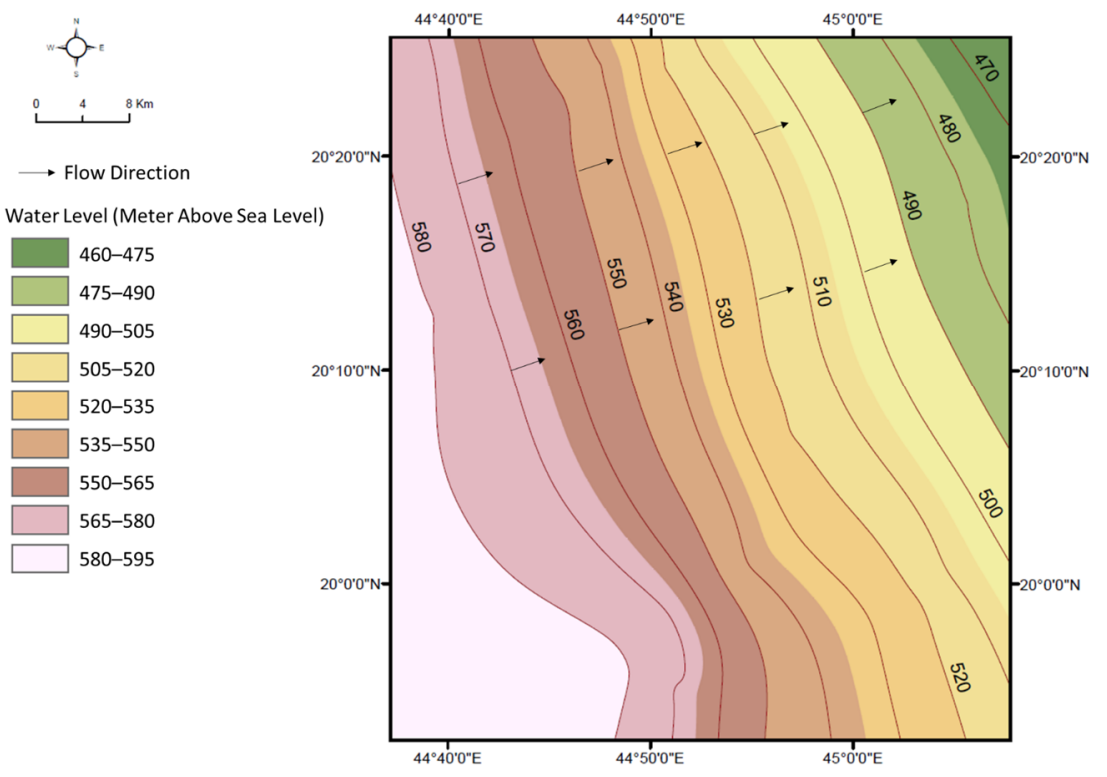

Figure 4. Groundwater level contour map of the Wajid aquifer.

This study aims to define the origins and hydrochemical processes of the groundwater in shallow and deep unconfined and confined parts of the Wajid aquifer in the Wadi Al-Dawasir area by analyzing the hydrochemical and isotopic data set.

\section{Materials and Methods}

Thirty-two groundwater samples were collected from 32 wells (Figure 1) tapping the Wajid aquifer (unconfined in the western part and confined in the eastern part of the study area) during March 2018. Groundwater samples from each well were collected in new polypropylene bottles ( $1 \mathrm{~L}$ ) for the ion concentration and isotopic composition, and after filtering using $0.45 \mu \mathrm{m}$ membrane. The water samples were collected from production wells 
after the water was pumped for more than one hour to make sure that the stagnant water has been removed. The in-situ hydrochemical parameters, including $\mathrm{pH}, \mathrm{EC}$, temperature, and TDS, were measured in the well using the multi-parameter meter (Hanna HI 9828 manufactured by Hanna Instruments company in Woonsocket, RI, USA). All water samples were stored at 4 degrees Celsius in an icebox.

Laboratory analysis was conducted in the Environmental and Hydrology Laboratory at King Fahd University of Petroleum and Minerals (KFUPM). Ion chromatography (IC) (method to separating ions according to their interactions) was used to measure the potassium $\left(\mathrm{K}^{+}\right)$, sodium $\left(\mathrm{Na}^{+}\right)$, calcium $\left(\mathrm{Ca}^{2+}\right)$, magnesium $\left(\mathrm{Mg}^{2+}\right)$, ammonium $\left(\mathrm{NH}_{4}{ }^{+}\right)$, chloride $\left(\mathrm{Cl}^{-}\right)$, nitrate $\left(\mathrm{NO}_{3}{ }^{-}\right)$, and sulfate $\left(\mathrm{SO}_{4}{ }^{2-}\right)$ in $\mathrm{mg} / \mathrm{L}$. The gravimetric method was used to measure the total dissolved solids (TDS), and the result was reported as $\mathrm{mg} / \mathrm{L}$. The colorimetric titration method was used to measure the bicarbonate $\left(\mathrm{HCO}_{3}\right)$.

Stable isotope ${ }^{2} \mathrm{H}$ and ${ }^{18} \mathrm{O}$ of the 20 groundwater samples were analyzed using a laser gas analyzer with off-axis integrated cavity output spectroscopy technology (LGR OA-ICOS) at the Environmental Isotope Laboratory, University of Waterloo, Canada. The Precision of the measurement of ${ }^{2} \mathrm{H}$ and ${ }^{18} \mathrm{O}$ are $0.8 \%$ VSMOW and $0.2 \%$ VSMOW, respectively. The results of ${ }^{2} \mathrm{H}$ and ${ }^{18} \mathrm{O}$ are reported as $\delta$-values, which describe the ratio to the international standard VSMOW (Vienna standard mean ocean water) established by the International Atomic Energy Agency.

\section{Results}

\subsection{Hydrochemical Characteristics}

To identify the origin and hydrochemical evolution of the groundwater, the hydrochemical properties of the water should be understood. The descriptive statistical parameters of the hydrochemical data of tested groundwater from the shallow unconfined, deep unconfined, and deep confined Wajid aquifers were obtained and presented in Table 1. As shown in Table 1, the deep unconfined aquifer has water with TDS in the ranges from 591 to $1116 \mathrm{mg} / \mathrm{L}$ with an average value of $755.5 \mathrm{mg} / \mathrm{L}$. The TDS of the shallow unconfined aquifer varies from 1670 to $2868 \mathrm{mg} / \mathrm{L}$ with an average value of $2226.6 \mathrm{mg} / \mathrm{L}$. The higher values of the TDS of groundwater in the shallow unconfined aquifer most probably related to salinization issues due to heavy agricultural activity for a long time and prevailing aridity climatic conditions. For the deep confined aquifer, the TDS varies from 1109 to $3600 \mathrm{mg} / \mathrm{L}$ with an average value of $2028 \mathrm{mg} / \mathrm{L}$. The $\mathrm{pH}$ values of groundwater from shallow unconfined, deep unconfined, and deep confined aquifer ranges from 7.0 to 7.0, 6.9 to 8.1 , and 8.0 to 8.0 , with the average values of $7.6,7.4$, and 7.5 , respectively. This result indicates that the groundwater in unconfined and confined aquifers is neutral to alkaline in nature. The average concentrations of the major cations in the deep unconfined aquifers follow the order of $\mathrm{Ca}^{2+}>\mathrm{Na}^{+}>\mathrm{Mg}^{2+}>\mathrm{K}^{+}$, however, the order in the shallow and the confined aquifer was $\mathrm{Na}^{+}>\mathrm{Ca}^{2+}>\mathrm{Mg}^{2+}>\mathrm{K}^{+}$with more sodium than calcium. The average concentration of the major anions in the shallow unconfined aquifer and deep confined one follows the order of $\mathrm{Cl}^{-}>\mathrm{SO}_{4}{ }^{2-}>\mathrm{HCO}_{3}{ }^{-}>\mathrm{NO}_{3}{ }^{2-}$ with a higher concentration of the chloride and sulfates ions. On the contrary, the deep unconfined aquifer displays an average concentration of anions with an order of $\mathrm{HCO}_{3}{ }^{-}>\mathrm{Cl}^{-}>\mathrm{SO}_{4}{ }^{2-}>\mathrm{NO}_{3}{ }^{2-}$ with more concentration of bicarbonate ion than others.

\subsection{Hydrochemical Facies}

The hydrochemical data of analyzed groundwater have been used to establish the Piper diagram to understand the processes controlling water chemistry and to identify the groundwater type [8]. As shown in Figure 5, the shallow unconfined, and deep confined aquifers are characterized by two types of groundwater, the $\mathrm{Cl}_{2} \mathrm{SO}_{4}-\mathrm{Ca}$. Na and $\mathrm{Cl}_{2} \mathrm{SO}_{4-}$ $\mathrm{Na}$. $\mathrm{Ca}$, in which the chloride and sulfate anions account for more than $85 \%$ of total anions, and calcium and sodium account for more than $90 \%$ of total cations. The deep unconfined groundwater is characterized by two water types, which are the $\mathrm{HCO}_{3}-\mathrm{Ca}$. Na, 
and $\mathrm{Cl} . \mathrm{HCO}_{3}-\mathrm{Ca}$. Na. The bicarbonate concentration is considerably higher in the deep unconfined groundwater than the shallow unconfined and deep confined ones.

Table 1. Descriptive statistics of the tested groundwater samples from the Wajid aquifer.

\begin{tabular}{|c|c|c|c|c|c|c|c|c|c|c|c|}
\hline & & $\begin{array}{c}\mathrm{Ca}^{2+} \\
(\mathrm{mg} / \mathrm{L})\end{array}$ & $\begin{array}{c}\mathrm{Mg}^{2+} \\
(\mathrm{mg} / \mathrm{L})\end{array}$ & $\begin{array}{c}\mathrm{Na}^{+} \\
(\mathrm{mg} / \mathrm{L})\end{array}$ & $\mathrm{K}^{+}(\mathrm{mg} / \mathrm{L})$ & $\begin{array}{l}\mathrm{HCO}_{3}^{-} \\
(\mathrm{mg} / \mathrm{L})\end{array}$ & $\begin{array}{c}\mathrm{Cl}^{-} \\
(\mathrm{mg} / \mathrm{L})\end{array}$ & $\begin{array}{c}\mathrm{SO}_{4}{ }^{2-} \\
(\mathrm{mg} / \mathrm{L})\end{array}$ & $\begin{array}{l}\mathrm{NO}_{3}{ }^{2-} \\
(\mathrm{mg} / \mathrm{L})\end{array}$ & $\begin{array}{c}\text { TDS } \\
(\mathrm{mg} / \mathrm{L})\end{array}$ & $\mathrm{pH}$ \\
\hline \multirow{3}{*}{$\begin{array}{l}\text { Shallow } \\
\text { unconfined } \\
\text { aquifer }\end{array}$} & Maximum & 380.00 & 44.70 & 481.00 & 13.10 & 147.90 & 1020.00 & 561.00 & 108.00 & 2868 & 8.1 \\
\hline & Minimum & 195.69 & 14.29 & 179.31 & 0.00 & 67.14 & 344.96 & 240.14 & 8.69 & 1670 & 7.0 \\
\hline & Average & 255.10 & 25.60 & 272.13 & 3.43 & 113.08 & 494.96 & 372.90 & 31.31 & 2226 & 7.6 \\
\hline \multirow{3}{*}{$\begin{array}{l}\text { Deep unconfined } \\
\text { aquifer }\end{array}$} & Maximum & 124.66 & 28.00 & 136.00 & 16.90 & 278.42 & 242.00 & 189.00 & 18.60 & 1116 & 8.0 \\
\hline & Minimum & 80.00 & 7.78 & 52.13 & 2.29 & 117.00 & 85.69 & 90.27 & 2.20 & 591 & 7.0 \\
\hline & Average & 98.42 & 18.36 & 87.84 & 7.48 & 171.68 & 161.70 & 131.67 & 6.86 & 755 & 7.4 \\
\hline \multirow{3}{*}{ Confined aquifer } & Maximum & 610.50 & 110.70 & 608.70 & 12.40 & 156.00 & 1115.00 & 1427.00 & 122.50 & 3600 & 8.0 \\
\hline & Minimum & 110.80 & 35.31 & 135.70 & 1.52 & 97.59 & 286.00 & 236.00 & 6.40 & 1109 & 6.9 \\
\hline & Average & 247.41 & 54.02 & 306.05 & 7.85 & 122.09 & 528.85 & 501.52 & 36.29 & 2028 & 7.5 \\
\hline
\end{tabular}

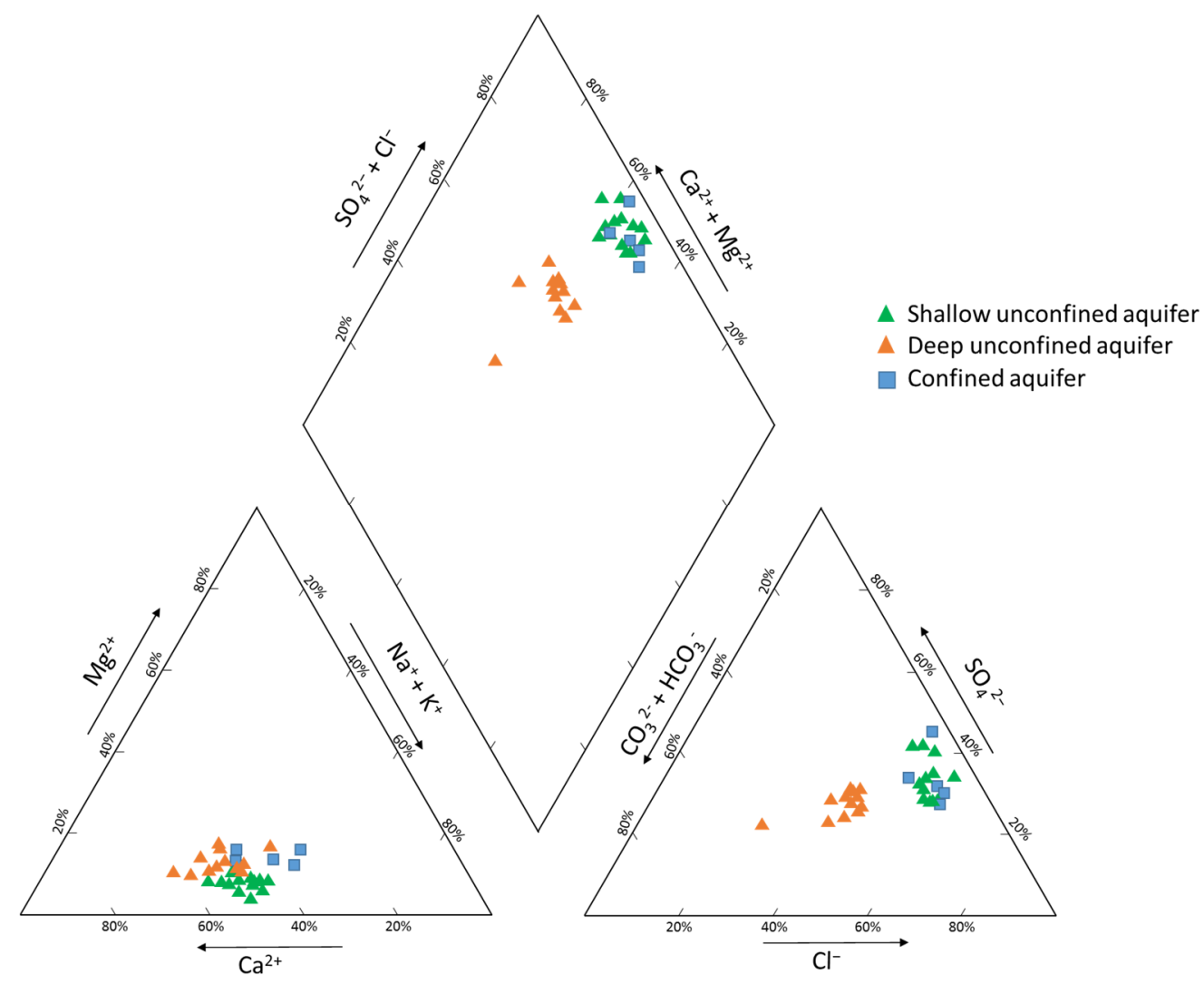

Figure 5. Piper plot for groundwater samples from shallow, deep unconfined, and deep confined Wajid aquifers in Wadi Al-Dawasir.

\subsection{Oxygen-18 and Deuterium Compositions}

Stable oxygen-18 and deuterium isotope values of the analyzed groundwater samples were reported in $\delta$ notation in per mill (\%) versus Vienna standard mean ocean water (VSMOW), and the results are shown in Table 2. The groundwater recharge source and the residence time are the main key controls on its isotopic composition. As shown in Table 2, the stable oxygen-18 and deuterium isotopic composition of the shallow unconfined groundwater vary from $-5.51 \%$ to $-3.34 \%$, and from $-38.53 \%$ to $-19.44 \%$, with average values of $-4.34 \%$ and $-26.87 \%$, respectively. For the deep unconfined groundwater, the $\delta^{18} \mathrm{O}$ and $\delta^{2} \mathrm{H}$ composition range from $-5.71 \%$ to $-3.28 \%$, and from $-31.69 \%$ to $-10.57 \%$, and average values of $-4.65 \%$ and $-22.67 \%$, respectively. The $\delta^{18} \mathrm{O}$ and $\delta^{2} \mathrm{H}$ composition of 
the unconfined groundwater vary from $-5.71 \%$ to $-3.54 \%$, and from $-37.50 \%$ to $-18.40 \%$ with averages of $-4.45 \%$ and $-28.25 \%$, respectively.

Table 2. Stable isotope data of 20 groundwater samples from Wajid aquifer.

\begin{tabular}{|c|c|c|c|}
\hline Sample Number & Aquifer & Oxygen-18 & Deuterium \\
\hline UW-01 & \multirow{10}{*}{$\begin{array}{c}\text { Shallow Unconfined } \\
\text { Aquifer }\end{array}$} & -4.46 & -24.99 \\
\hline UW-04 & & -3.93 & -20.06 \\
\hline $\mathrm{UW}-05$ & & -4.03 & -21.62 \\
\hline UW-06 & & -4.53 & -28.18 \\
\hline UW-09 & & -4.79 & -30.13 \\
\hline $\mathrm{UW}-10$ & & -5.09 & -34.08 \\
\hline $\mathrm{UW}-11$ & & -5.51 & -38.53 \\
\hline $\mathrm{UW}-12$ & & -3.77 & -25.17 \\
\hline $\mathrm{UW}-13$ & & -3.34 & -19.44 \\
\hline $\mathrm{UW}-14$ & & -3.93 & -26.49 \\
\hline Min & & -5.51 & -38.53 \\
\hline Max & & -3.34 & -19.44 \\
\hline Average & & -4.34 & -26.87 \\
\hline UW-02 & \multirow{5}{*}{$\begin{array}{c}\text { Deep Unconfined } \\
\text { Aquifer }\end{array}$} & -5.71 & -31.69 \\
\hline $\mathrm{UW}-03$ & & -4.40 & -21.96 \\
\hline UW-07 & & -4.49 & -20.94 \\
\hline UW-08 & & -3.28 & -10.57 \\
\hline UW-20 & & -5.35 & -28.20 \\
\hline Min & & -5.71 & -31.69 \\
\hline $\operatorname{Max}$ & & -3.28 & -10.57 \\
\hline Average & & -4.65 & -22.67 \\
\hline UW-15 & \multirow{5}{*}{ Unconfined Aquifer } & -4.01 & -25.82 \\
\hline $\mathrm{UW}-16$ & & -3.73 & -25.14 \\
\hline $\mathrm{UW}-17$ & & -5.71 & -37.50 \\
\hline $\mathrm{UW}-18$ & & -5.25 & -34.40 \\
\hline UW-19 & & -3.54 & -18.40 \\
\hline Min & & -5.71 & -37.50 \\
\hline Max & & -3.54 & -18.40 \\
\hline Average & & -4.45 & -28.25 \\
\hline
\end{tabular}

\section{Discussion}

\subsection{Hydrochemical Processes Controlling Water Chemistry}

Determination of the hydrochemical processes that control the chemistry of tested groundwater was achieved through the establishment of a Gibbs plot and bivariate analysis of the hydrochemical data. The Gibbs plot usually displays three major hydrochemical processes, including rock weathering, evaporation, and precipitation. As shown in Figure 6, the Gibbs plot of the tested groundwater samples was established by plotting the data of a TDS versus $\mathrm{Na} /(\mathrm{Na}+\mathrm{Ca})$. Generally, the studied groundwater samples were plotted in the regions of rock weathering and evaporation dominances. Samples from the deep unconfined groundwater plotted within the zone of the rock-weathering dominance, indicating the aquifer matrix mineralogy effect on the water chemistry. On the contrary, the samples from the shallow unconfined and deep confined aquifers were plotted in a transition zone between rock-weathering evaporation dominance regions, indicating the weathering of rock-forming minerals of Wajid sandstone is the primary process and evaporation as a secondary process controlling the chemistry of groundwater. 


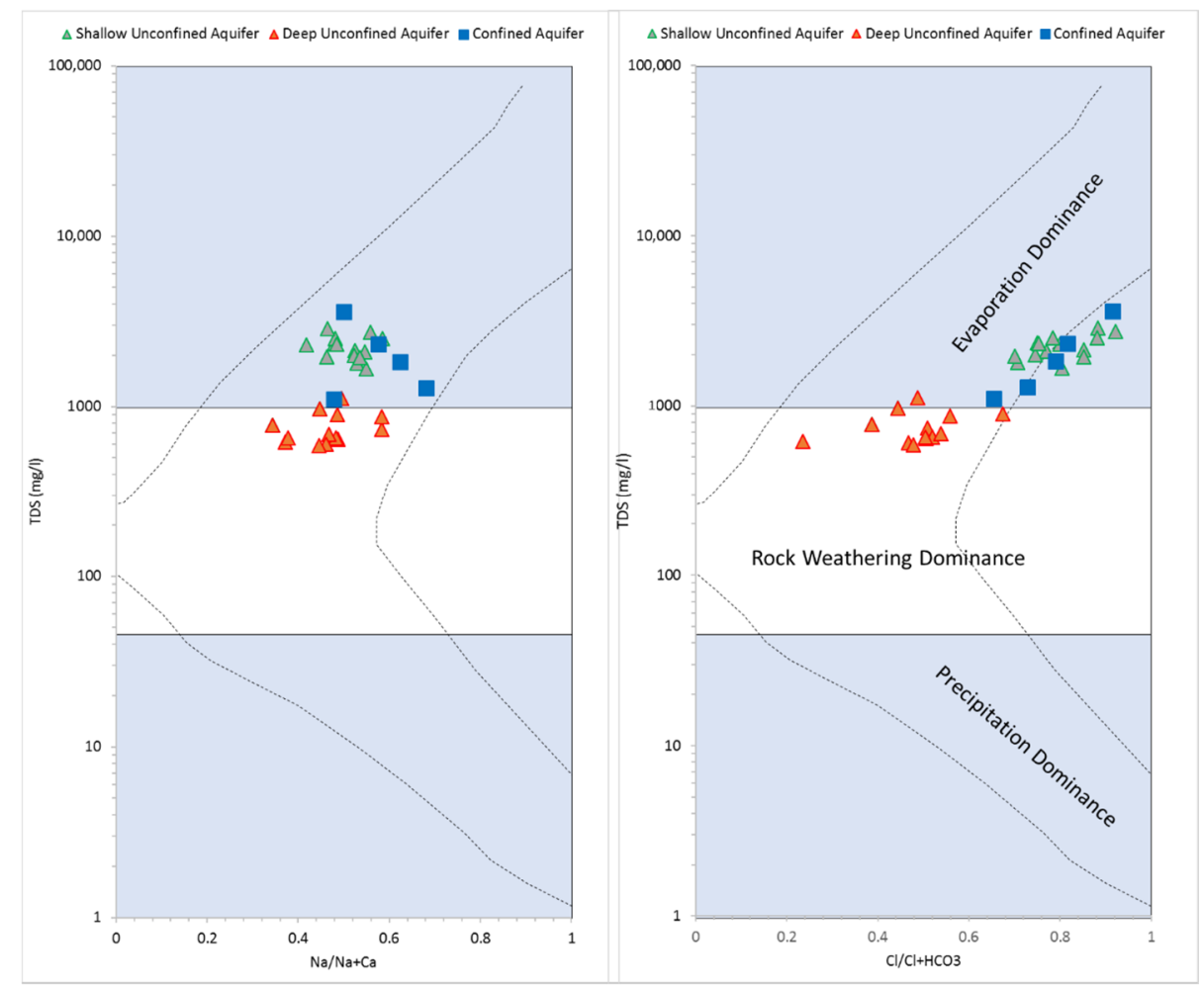

Figure 6. Gibbs diagram of the collected groundwater samples from Wajid aquifer.

\subsubsection{Weathering Process}

The presence of calcium $\left(\mathrm{Ca}^{2+}\right)$ and sodium $\left(\mathrm{Na}^{+}\right)$, chloride $\left(\mathrm{Cl}^{-}\right)$, sulfate $\left(\mathrm{SO}_{4}{ }^{2-}\right)$, and bicarbonate $\left(\mathrm{HCO}_{3}{ }^{-}\right)$as dominant ions in the Wajid aquifer indicating the rock-forming minerals of Wajid sandstone (calcite, dolomite, gypsum, anhydrite, halite) are most likely the source of the major ions. For the $\mathrm{Ca}^{2+}+\mathrm{HCO}_{3}{ }^{-}, \mathrm{Ca}^{2+}+\mathrm{Mg}^{2+}+\mathrm{HCO}_{3}{ }^{-}, \mathrm{Ca}^{2+}+\mathrm{SO}_{4}{ }^{2-}$, the possible source is the dissolution of the calcite $\left(\mathrm{CaCO}_{3}\right)$, dolomite $\left(\mathrm{CaMg}\left(\mathrm{CO}_{3}\right)_{2}\right)$, and gypsum $\left(\mathrm{CaSO}_{4} \cdot 2 \mathrm{H}_{2} \mathrm{O}\right)$ and anhydrite $\left(\mathrm{CaSO}_{4}\right)$, respectively. This interpretation was verified by studying the relationship between the ions concentration of the tested groundwater samples. As shown in Figure $7 \mathrm{~A}, \mathrm{Ca}+\mathrm{Mg}$ versus $\mathrm{HCO}_{3}+\mathrm{SO}_{4}$ plot shows that groundwater samples from deep unconfined aquifer fall along or close the equiline $1: 1$, indicating the weathering process of either carbonate or sulfate minerals or both as the main control on the concentration of ions in water composition [9]. However, by plotting of $\mathrm{Ca}$ versus $\mathrm{SO}_{4}$ (indicating evaporitic minerals dissolution) as shown in (Figure 7B), none of the tested groundwater falls along the equiline 1:1; thus, no contribution of gypsum or anhydrite on the water chemistry. Plotting of $\mathrm{Ca}$ versus $\mathrm{HCO} 3$ of the tested groundwater shows that the samples fall between equiline 1:1 and line 1:2, indicating the contribution of calcite minerals on the chemistry of groundwater samples from the deep unconfined aquifer (Figure 7C). The calcite mineral is mainly derived from carbonate cemented materials of Wajid sandstone, as it has been documented by several researchers [10-17].

The contribution of halite mineral on the ion concentration of the tested groundwater has been studied by plotting $\mathrm{Na}$ versus $\mathrm{Cl}$, as shown in Figure 7D. The majority of groundwater samples from unconfined and confined sections located below the $\mathrm{Na}: \mathrm{Cl}$ equiline indicate an excess of $\mathrm{Cl}$ over $\mathrm{Na}$, which implies another source of $\mathrm{Cl}$, or loss of $\mathrm{Na}$ by reverse exchange reaction with $\mathrm{Ca}$. Three samples from a deep unconfined section and two samples from shallow unconfined and confined ones located along with the Na: $\mathrm{Cl}$ equiline reveal a significant contribution of halite mineral on the water chemistry of those samples (Figure 7D). Two samples from each section, the shallow unconfined and confined ones plotted above $\mathrm{Na}$ : $\mathrm{Cl}$ equiline, in $\mathrm{Na}$ side, indicating an excess of $\mathrm{Na}$ over $\mathrm{Cl}$, which means an extra source of $\mathrm{Na}$, most probably silicate weathering (Na-rich plagioclase). 
The plagioclase mineral comes from the Wajid sandstone (particularly from Khusayyayn Formation) [17].

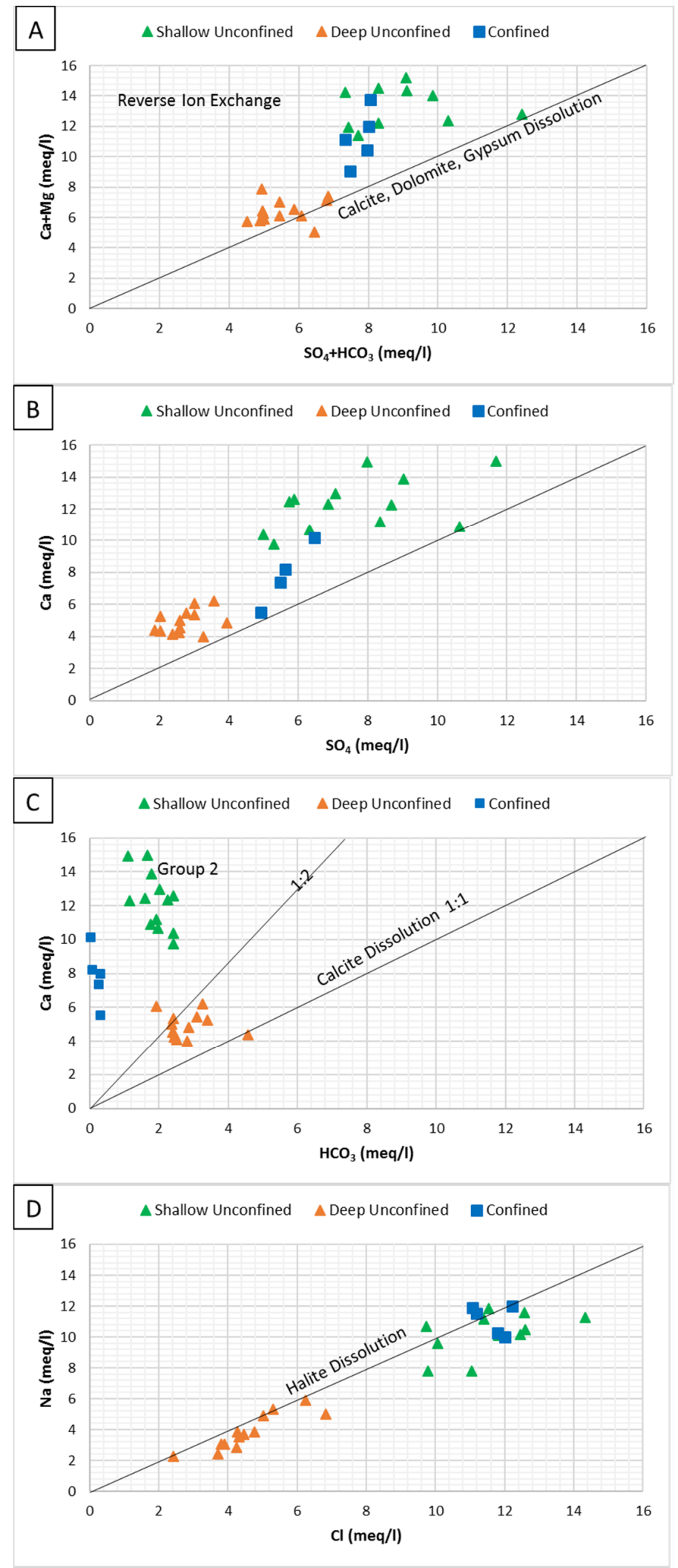

Figure 7. Scatter plots showing the relationship between (A) $\mathrm{Ca}+\mathrm{Mg}$ and $\mathrm{SO}_{4}+\mathrm{HCO}_{3}$, (B) $\mathrm{Ca}$ and $\mathrm{SO}_{4},(\mathbf{C}) \mathrm{Ca}$ and $\mathrm{HCO}_{3}$, and (D) $\mathrm{Na}$ and $\mathrm{Cl}$. 


\subsubsection{Ion Exchange Process}

One of the most important processes that play a major role in ion concentration in the groundwater is the ion exchange process. This process can be either normal or reverse, where, in the normal ion exchange processes, the $\mathrm{Ca}$ or $\mathrm{Mg}$ in the groundwater exchange with $\mathrm{Na}$ and $\mathrm{K}$ in the aquifer lithology (rock); however, in the reverse ion exchange process, the $\mathrm{Na}$ and $\mathrm{K}$ from groundwater exchange with $\mathrm{Ca}$ or $\mathrm{Mg}$ from aquifer lithology [18]. The occurrence of the ion exchange process (normal or reverse) can be determined by calculating the chloro-alkaline indices (CAI-1 and CAI-2) using the following equations, where the concentrations of the ions are expressed in meq/1 [19]:

$$
\begin{gathered}
\mathrm{CAI}-1=\mathrm{Cl}^{-}-\left(\mathrm{Na}^{+}+\mathrm{K}^{+}\right) / \mathrm{Cl}^{-} \\
\mathrm{CAI}-2=\mathrm{Cl}^{-}-\left(\mathrm{Na}^{+}+\mathrm{K}^{+}\right) / \mathrm{SO}_{4}{ }^{2-}+\mathrm{HCO}_{3}{ }^{-}+\mathrm{NO}_{3}{ }^{-}
\end{gathered}
$$

The calculated CAI-1 and CAI-2 of the analyzed groundwater samples are shown in Figure 8 . Around $75 \%$ of the analyzed groundwater samples are characterized by positive CAI values, indicating the effect of reverse ion exchange. On the contrary, $22 \%$ of the tested groundwater samples have negative CAI values, which reveal the occurrence of the normal ion exchange process.

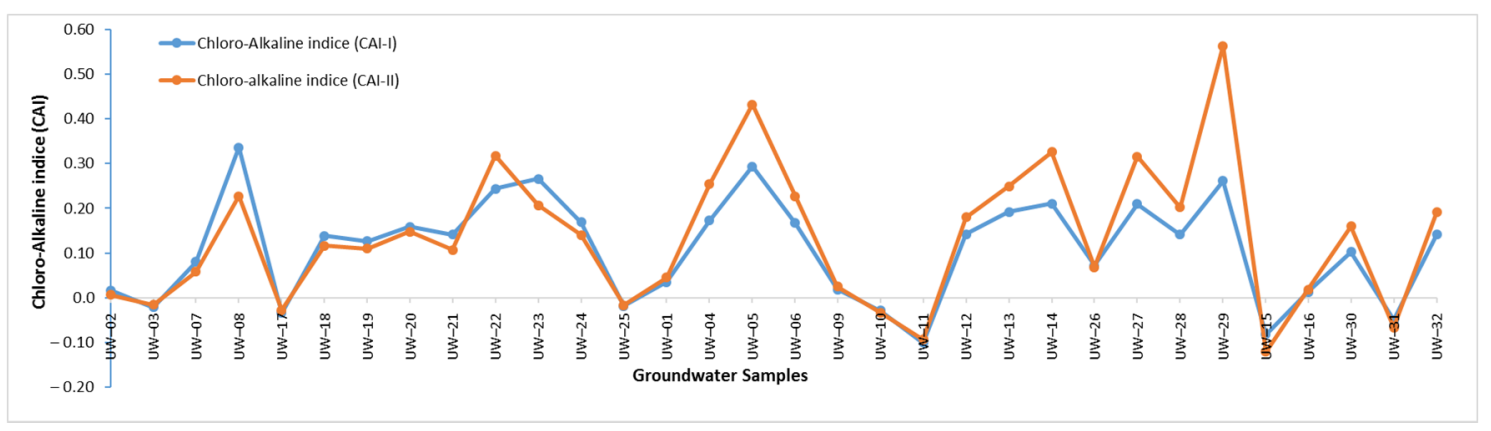

Figure 8. Chloro-alkaline indices (CAI) of analyzed groundwater samples.

The reverse ion exchange process acted to replace $\mathrm{Na}$ in water with $\mathrm{Ca}$ and $\mathrm{Mg}$ from the aquifer matrix. This led to a decrease in Na concentration in groundwater samples.

\subsection{Saturation Indices}

Saturation indices of calcite, dolomite, gypsum, anhydrite, and halite minerals for the tested groundwater were calculated using PHREEQC 3.0 [20], and the results are shown in Table 3. The saturation indices (SI) elucidate the state of the aforementioned minerals in groundwater (equilibrium $(S I=0)$, oversaturated $(S I>0)$, undersaturated $(S I<0)$ ), which can help to identify the geochemical reaction controlling the groundwater chemistry [21]. The results show that the analyzed groundwater samples are oversaturated with calcite and dolomite, which indicates the possibility of calcite and dolomite precipitation. The calcite and dolomite minerals come from the aquifer matrix, which is mainly sandstone with a significant amount of carbonate minerals as cemented materials. The SI of calcite and dolomite increases through the dissolution of these minerals in groundwater. In contrast, the analyzed groundwater samples are undersaturated with gypsum, anhydrite, and halite minerals, indicating the dissolution of such minerals could have occurred if these minerals present in the aquifer matrix. The relationship between the saturation indices (SI) of calcite and dolomite with TDS shows that the saturation of carbonate minerals (calcite and dolomite) decreases with an increase in the TDS of the groundwater; thus, less contribution of carbonate minerals in the TDS (Figure 9). 
Table 3. Saturation indices (SI) of carbonate and evaporate minerals for the tested groundwater samples.

\begin{tabular}{|c|c|c|c|c|c|c|}
\hline Sample ID & Aquifer & Calcite SI & Dolomite SI & Gypsum SI & Anhydrite SI & Halite SI \\
\hline UW-02 & \multirow{11}{*}{$\begin{array}{c}\text { Deep } \\
\text { unconfined } \\
\text { aquifer }\end{array}$} & 1.95 & 3.3 & -1.69 & -1.87 & -6.95 \\
\hline UW-03 & & 1.9 & 3.22 & -1.67 & -1.85 & -6.96 \\
\hline UW-07 & & 1.82 & 3.14 & -1.31 & -1.49 & -6.26 \\
\hline $\mathrm{UW}-08$ & & 1.79 & 3.11 & -1.44 & -1.62 & -6.49 \\
\hline UW-17 & & 1.66 & 3.26 & -1.52 & -1.7 & -6.32 \\
\hline UW-18 & & 1.64 & 3.09 & -1.56 & -1.74 & -6.52 \\
\hline UW-19 & & 1.64 & 3.08 & -1.53 & -1.72 & -6.48 \\
\hline UW-20 & & 1.67 & 3.01 & -1.49 & -1.68 & -6.44 \\
\hline UW-21 & & 1.65 & 3.12 & -1.59 & -1.78 & -6.63 \\
\hline$U W-22$ & & 1.59 & 2.87 & -1.37 & -1.56 & -6.18 \\
\hline UW-23 & & 1.68 & 3.08 & -1.4 & -1.59 & -6.62 \\
\hline $\mathrm{UW}-24$ & \multirow{16}{*}{$\begin{array}{c}\text { Shallow } \\
\text { unconfined } \\
\text { aquifer }\end{array}$} & 1.51 & 3.46 & -1.74 & -1.93 & -6.64 \\
\hline$U W-25$ & & 1.69 & 3.28 & -1.38 & -1.57 & -6.15 \\
\hline UW-01 & & 1.76 & 2.92 & -1.03 & -1.22 & -5.74 \\
\hline UW-04 & & 1.74 & 2.86 & -0.92 & -1.11 & -5.64 \\
\hline UW-05 & & 1.55 & 2.46 & -0.91 & -1.1 & -5.8 \\
\hline $\mathrm{UW}-06$ & & 1.65 & 2.74 & -0.84 & -1.03 & -5.62 \\
\hline UW-09 & & 1.62 & 2.61 & -0.93 & -0.93 & -5.63 \\
\hline $\mathrm{UW}-10$ & & 1.36 & 2.07 & -0.77 & -0.77 & -5.61 \\
\hline $\mathrm{UW}-11$ & & 1.62 & 2.46 & -0.81 & -0.81 & -5.72 \\
\hline UW-12 & & 1.7 & 2.8 & -0.86 & -0.86 & -5.66 \\
\hline $\mathrm{UW}-13$ & & 1.74 & 2.85 & -1.02 & -1.02 & -5.85 \\
\hline UW-14 & & 1.33 & 2.09 & -0.75 & -0.75 & -5.54 \\
\hline UW-26 & & 1.6 & 2.62 & -0.75 & -0.94 & -5.58 \\
\hline $\mathrm{UW}-27$ & & 1.63 & 2.72 & -0.75 & -0.95 & -5.36 \\
\hline UW-28 & & 1.59 & 2.69 & -0.65 & -0.85 & -5.16 \\
\hline UW-29 & & 1.55 & 2.56 & -0.65 & -0.85 & -4.99 \\
\hline $\mathrm{UW}-15$ & \multirow{5}{*}{$\begin{array}{l}\text { Confined } \\
\text { aquifer }\end{array}$} & 1.48 & 2.73 & -1.08 & -1.26 & -5.62 \\
\hline $\mathrm{UW}-16$ & & 1.46 & 2.7 & -0.97 & -1.14 & -5.58 \\
\hline $\mathrm{UW}-30$ & & 1.62 & 3.26 & -1.3 & -1.48 & -5.65 \\
\hline $\mathrm{UW}-31$ & & 1.69 & 3.22 & -1.11 & -1.29 & -6.05 \\
\hline UW-32 & & 1.61 & 2.88 & -0.17 & -0.35 & -4.89 \\
\hline
\end{tabular}

The SI of evaporite minerals (gypsum, anhydrite, and halite) increases with increase TDS, reveals a significant contribution of such minerals in the salinity of the tested groundwater (Figure 9). The relationships between the $\mathrm{Ca}+\mathrm{HCO}_{3}, \mathrm{Ca}+\mathrm{Mg}+\mathrm{HCO}_{3}, \mathrm{Ca}+\mathrm{SO}_{4}$, $\mathrm{Na}+\mathrm{Cl}$ with calcite $\mathrm{SI}$, dolomite SI, gypsum SI, and halite SI, respectively, were studied as shown in Figures 10 and 11, to define the contribution of each mineral on the chemical composition of tested groundwater. The significant correlation observed between the $\mathrm{Ca}+\mathrm{HCO}_{3}$ and calcite SI of analyzed groundwater samples from the deep unconfined aquifer (Figure 10A) reveals an effect of carbonate minerals dissolution on the chemistry of the tested water. On the contrary, no correlation was observed between $\mathrm{Ca}+\mathrm{HCO}_{3}$ and calcite SI of groundwater samples from shallow unconfined, and deep confined aquifers. The relationship between dolomite $\mathrm{SI}$ and $\mathrm{Ca}+\mathrm{Mg}+\mathrm{HCO}_{3}$ was studied as shown in 
Figure 10B. The result shows only a weak correlation between dolomite $\mathrm{SI}$ and $\mathrm{Ca}+\mathrm{Mg}+$ $\mathrm{HCO}_{3}$ of groundwater from a deep unconfined aquifer and no correlation of groundwater from shallow unconfined and confined aquifers. Thus, dolomite has less influence on the chemistry of the studied groundwater than calcite minerals.

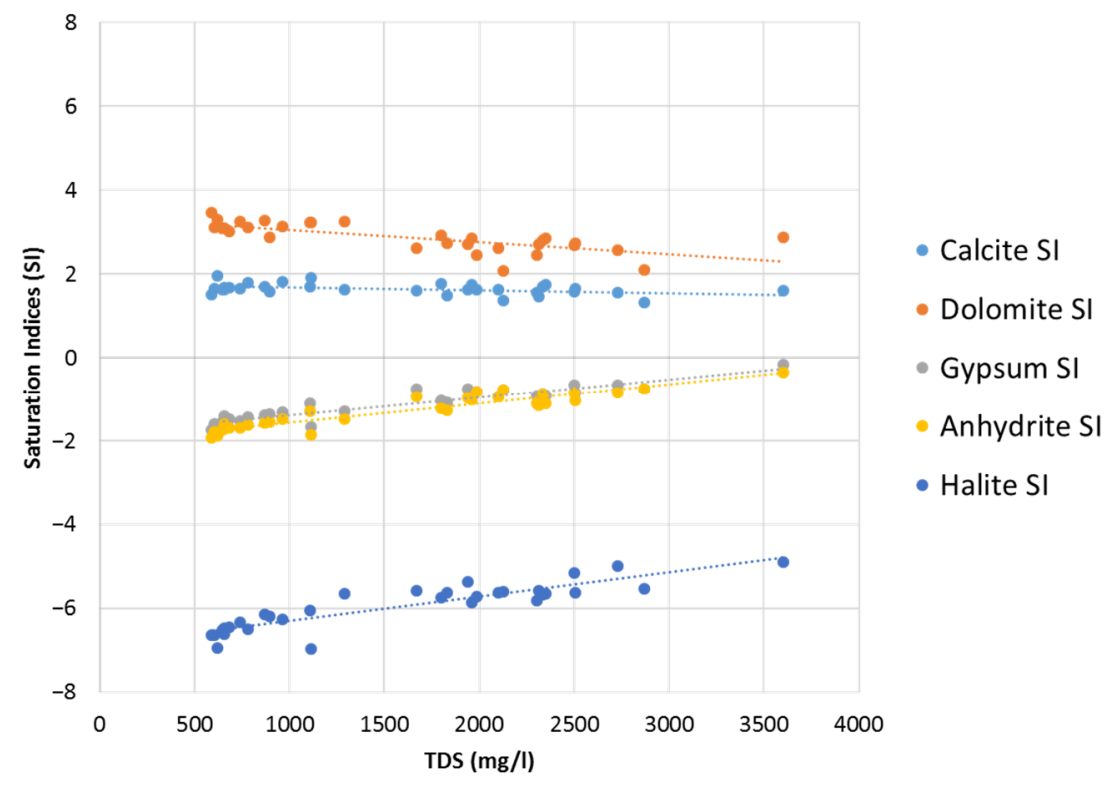

Figure 9. Scatter plots showing the relationship between TDS and the saturation indices of calcite, dolomite, gypsum, anhydrite, and halite minerals.
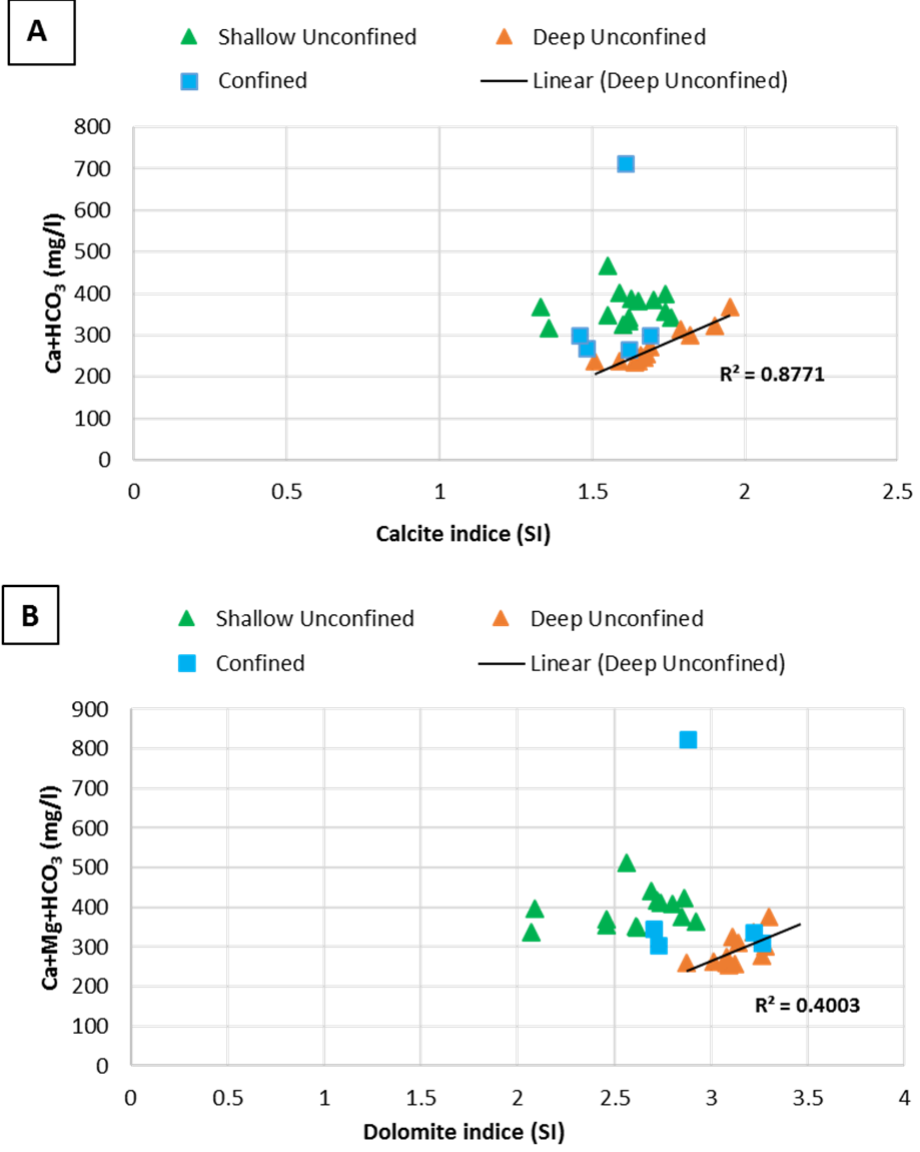

Figure 10. Scatter plots showing the relationship between (A) calcite SI and $\mathrm{Ca}+\mathrm{HCO}_{3},(\mathbf{B})$ dolomite $\mathrm{SI}$ and $\mathrm{Ca}+\mathrm{Mg}+\mathrm{HCO}_{3}$. 


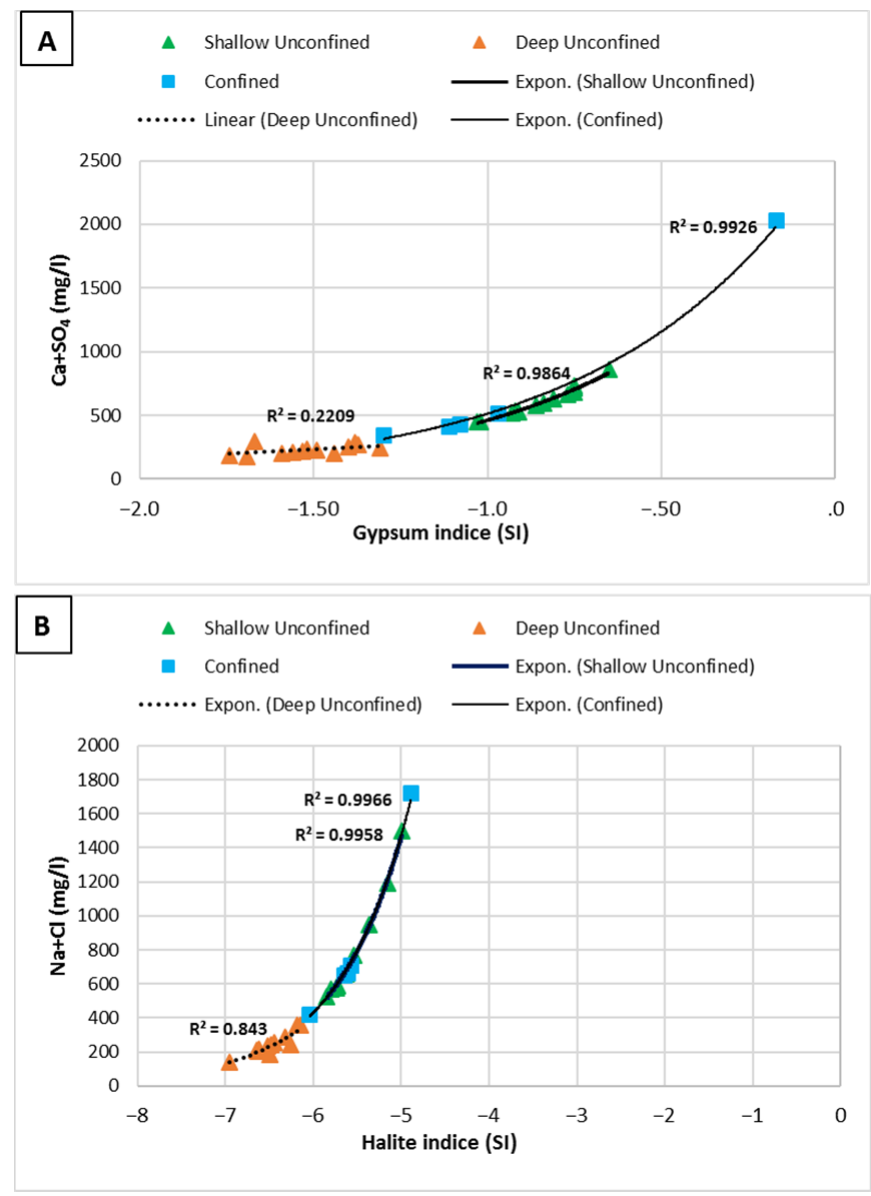

Figure 11. Scatter plots showing the relationship between (A) gypsum SI and $\mathrm{Ca}+\mathrm{SO}_{4}$ and (B) halite $\mathrm{SI}$ and $\mathrm{Na}+\mathrm{Cl}$.

A significant correlation was observed between the $\mathrm{Ca}+\mathrm{SO}_{4}$ and gypsum SI of groundwater samples from shallow unconfined and deep confined aquifers, and a weak correlation of groundwater samples from deep unconfined (Figure 11A). The results indicate more influence of gypsum dissolution on the chemistry of groundwater in shallow unconfined and confined aquifer than the deep unconfined. As shown in Figure 10B, a strong correlation observed between $\mathrm{Na}+\mathrm{Cl}$ and halite $\mathrm{SI}$ for all analyzed groundwater samples indicating a significant influence of dissolution of halite mineral on the chemistry of groundwater (Figure 10A,B). The salty soil in the Wadi Al-Dawasir area most probably be the source of the evaporite minerals.

\subsection{Groundwater Origin}

Several factors are documented in the literature that controls the isotopic composition of the groundwater. Among them, the recharge source, flow path, and residence time of groundwater [22]. The origin of the mixing of groundwater is usually determined through the analysis of the relationship of stable oxygen-18 and deuterium isotopes and compared to the local and global precipitation lines [23]. The local meteoric water line (LMWL) of Riyadh, Saudi Arabia that established by Michelsen and others, 2015, $\left(\delta^{2} \mathrm{H}=5.22 . \delta^{18} \mathrm{O}\right.$ $+14.8 \%$ ) was used in this study [24]. The LMWL and GMWL of precipitation were used to determine the origin of the tested groundwater samples. The isotopic composition of the tested groundwater samples was plotted and compared with local and global precipitation lines. As shown in Figure 12, the tested groundwater samples plotted along or nearly close to GMWL and below the LMWL lines, indicating the meteoric origin of the tested groundwater. The groundwater samples from the deep unconfined aquifer are relatively enriched by deuterium isotope compared to the shallow unconfined and deep 
confined ones. The samples from deep unconfined aquifers occurred between the LMWL and GMWL; however, the samples from shallow unconfined and deep confined aquifers occurred along or below the GMWL. This indicates that the groundwater from the deep confined aquifer is slightly depleted due to depth increasing. However, the relative isotopic depletion of the shallow unconfined groundwater reflected the depletion of recharge water, which most probably indicates the role of evaporation processes.

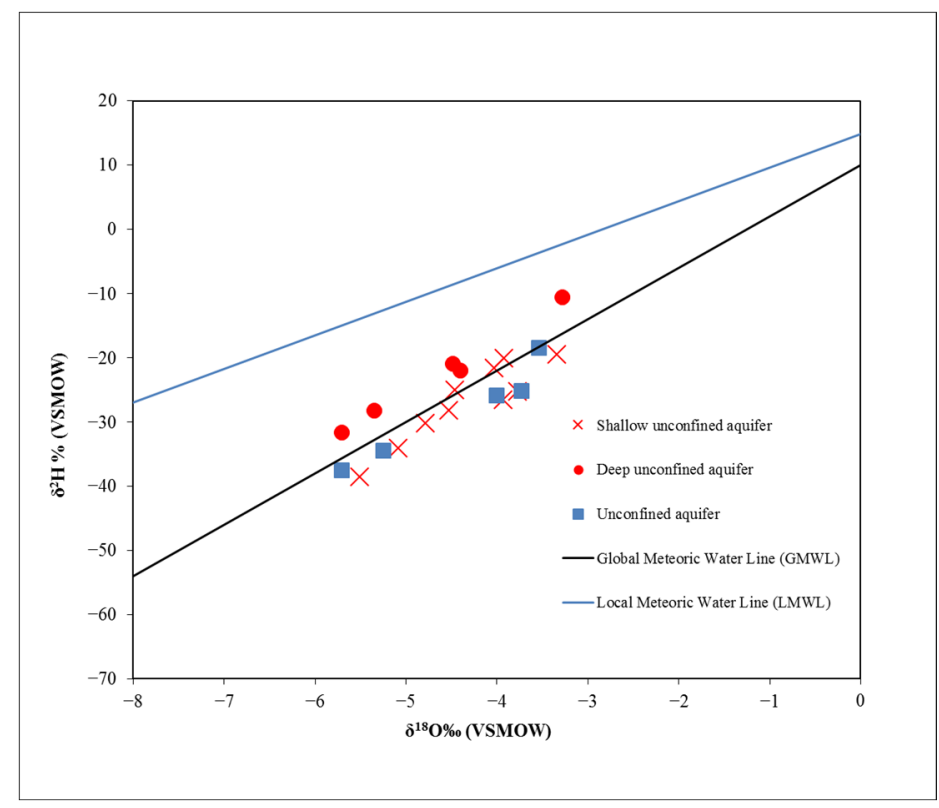

Figure 12. $\delta^{18} \mathrm{O}$ and $\delta^{2} \mathrm{H}$ ratios of tested groundwater from unconfined and confined sections of the Wajid aquifer.

The values of the deuterium excess $(\mathrm{d})$ of the tested groundwater samples were calculated $\left(\mathrm{d}=\delta^{2} \mathrm{H}-8 \times \delta^{18} \mathrm{O}\right)$. The calculated d-excess values of the studied groundwater vary within a range of $4.7 \%$ to $15.7 \%$ (Figure 13 ). The d-excess values of groundwater from wells tapped shallow unconfined aquifer (recharge area) and the deep confined aquifer is below the d-excess value of the global precipitation (10), indicating that the evaporation process most likely influenced the rainwater before recharging the aquifer.

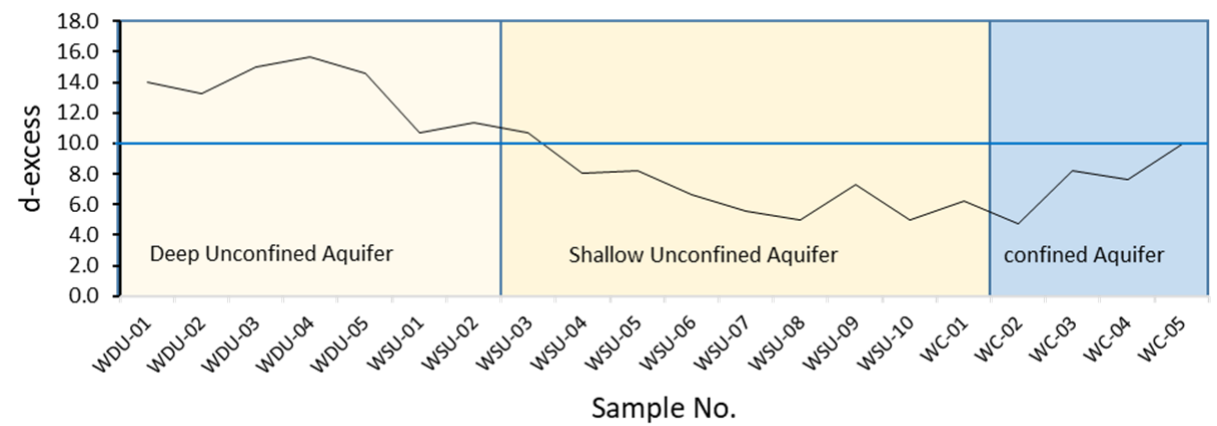

Figure 13. Values of d-excess of tested groundwater samples.

\subsection{Spatial Distribution of Salinity}

The spatial distribution of TDS of the tested groundwater samples was studied to delineate the lateral variation in groundwater salinity. As shown in Figure 14, groundwater wells tapped shallow unconfined aquifer (western part of the study area), and confined parts (eastern part of the study area) show a higher value of TDS than the wells tapped the deep unconfined aquifer (middle part of the study area). 


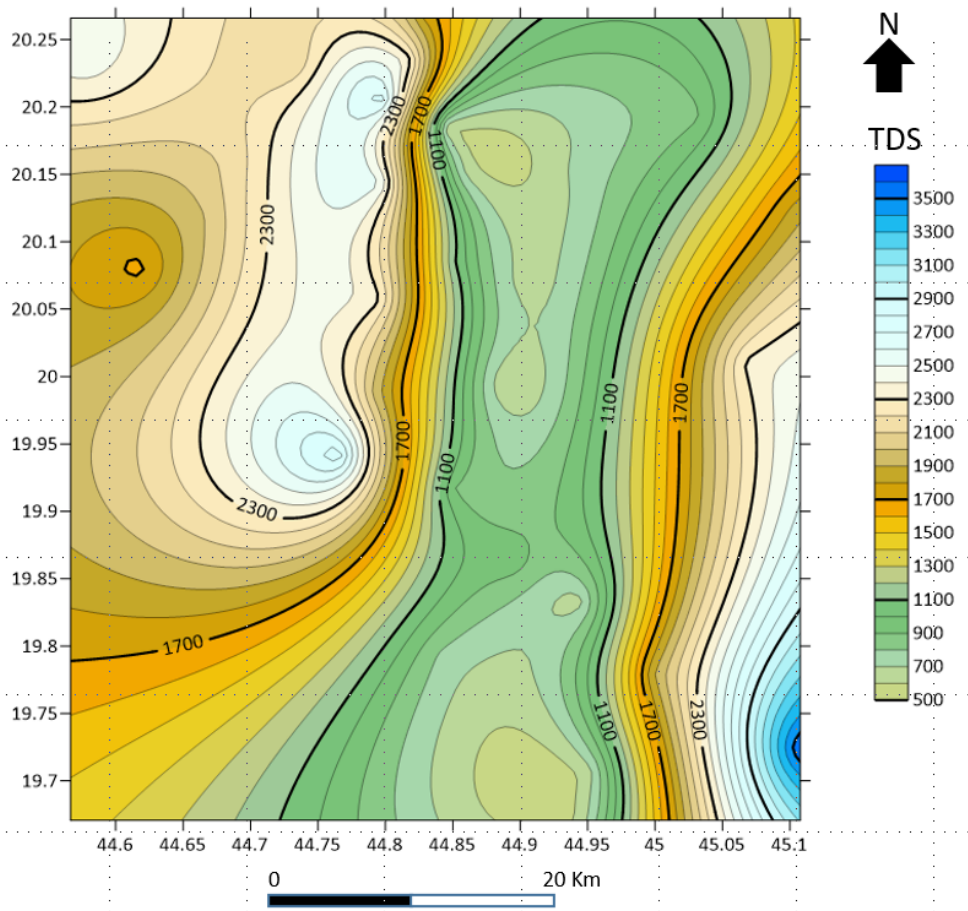

Figure 14. Spatial map shows the distribution of TDS of the studied groundwater.

The reverse pattern of TDS (higher values in recharge area) is attributed to agriculturalderived salt deposits that formed due to long and extensive agricultural activity in the study area with aridity climate conditions. In addition, the existence of high-density open fractures within the Wajid aquifer facilitates the downflow of return saline water (Figure 15). The presence of N-S and E-W trending sets of open and vertical fractures within Wajid sandstone (hosting Wajid aquifer), reported in the literature by $[25,26]$.

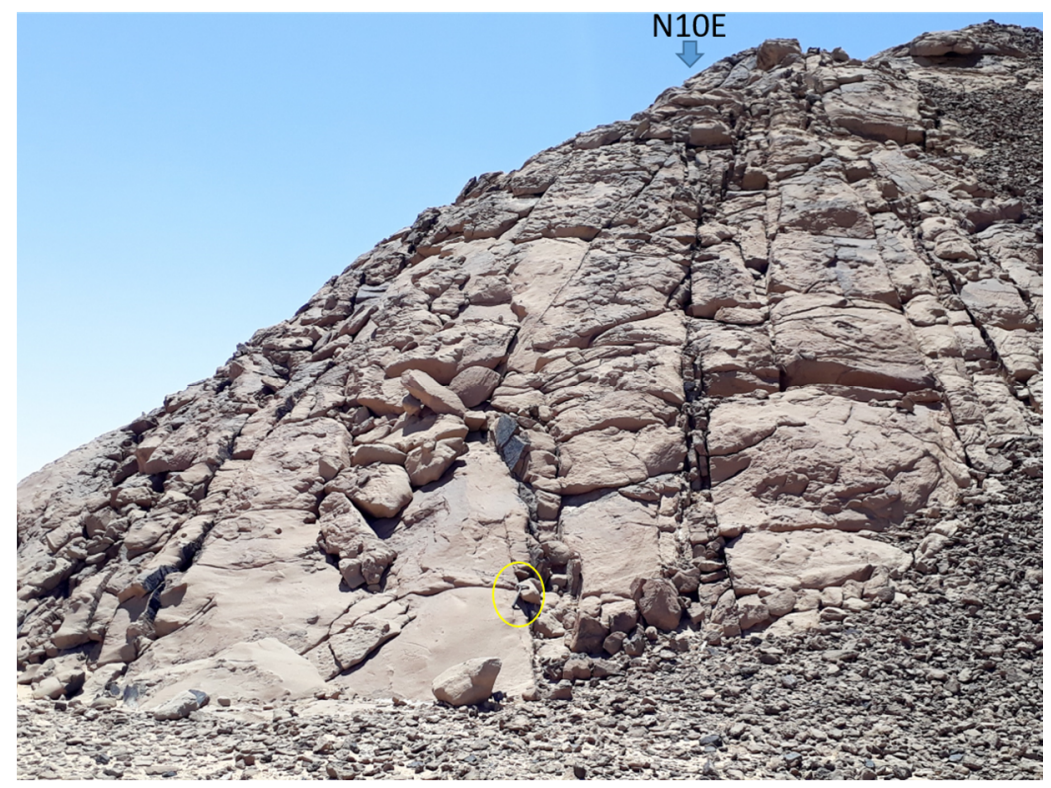

Figure 15. Photograph shows the N10 E-trending fracture set within the Wajid sandstone outcrop close to an agricultural area, Wadi Al-Dawasir.

\section{Conclusions}

The groundwater in the Wajid aquifer is fossils and non-renewable and displays two distinctive facies, $\mathrm{Ca}-\mathrm{Na}-\mathrm{Cl}-\mathrm{SO}_{4}$ and $\mathrm{Ca}-\mathrm{Na}-\mathrm{Cl}-\mathrm{SO}_{4}-\mathrm{HCO}_{3}$. The identified hydrochemical 
processes controlling water chemistry are weathering process, evaporation, and ion exchange. Dissolution of carbonate minerals (calcite) identified as the main hydrochemical process affected the groundwater chemistry of deep unconfined aquifer. On the contrary, evaporation and ion exchange processes have more influence on the groundwater chemistry of shallow unconfined and deep confined aquifers. The groundwater in the studied aquifer is of meteoric origin according to its isotopic composition. Shallow unconfined and deep confined aquifers have groundwater slightly depleted in deuterium isotope composition that reflected the influence of evaporation on infiltrated rainwater. The results of this study show that the groundwater in the Wajid aquifer flows from southwest to northeast, with higher salinity in the recharge area. This reverse pattern of salinity is mostly related to the irrigated return saline water. The saline water percolated through open fractures as a preferential conduit.

Author Contributions: Conceptualization, M.B. and A.A.-S.; methodology, M.B. and A.A.-S.; formal analysis, M.B. and A.A.-S.; investigation, M.B. and A.A.-S.; resources, M.B. and A.A.-S.; data curation, M.B.; writing—original draft preparation, M.B.; writing—review and editing, M.B. and A.A.-S.; visualization, M.B.; supervision, A.A.-S.; funding acquisition, A.A.-S. All authors have read and agreed to the published version of the manuscript.

Funding: This research was funded by the College of Petroleum Engineering \& Geosciences at KFUPM, grant number SF18060. And the APC was funded by the Deanship of Scientific Research, King Fahd University of Petroleum and Minerals.

Institutional Review Board Statement: Not applicable.

Informed Consent Statement: Not applicable.

Data Availability Statement: Not applicable.

Acknowledgments: The authors would like to acknowledge the King Fahd University of Petroleum and Minerals for all support and assistance provided for field and laboratory studies.

Conflicts of Interest: The authors declare no conflict of interest.

\section{References}

1. Ministry of Water \& Electricity (MoWE). Ministry of Water E Electricity: Detailed Water Resources Studies of Wajid and Overlying Aquifers; Association with GTZ/DCO—Gesellschaft für Technische Zusammenarbeit \& Dornier Consulting; MoWE: Riyadh, Saudi Arabia, 2010; Volume 16, unpublished.

2. Zhou, P.; Li, M.; Lu, Y. Hydrochemistry and isotope hydrology for groundwater sustainability of the coastal multilayered aquifer system (Zhanjiang, China). Geofluids 2017, 2017. [CrossRef]

3. Powers, R.W.; Ramirez, L.F.; Redmond, C.D.; Elberg, E.L.J. Geology of the Arabian Peninsula Sedimentary Geology of Saudi Arabia. U.S. Geol. Surv. Prof. Pap. 1966, 560-D, 154.

4. Kellogg, K.S.; Fourniguet, J.; Janjou, J.; Minoux, L. Geologic Map of the Wadi Tathlith Quadrangle; Sheet-20G, Saudi Arabian Deputy Ministry for Mineral Resources, Map GM-103 A, Scale; Saudi Arabian Deputy Ministry for Mineral Resources: Riyadh, Saudi Arabia, 1986.

5. Edgell, H.S. Aquifers of Saudi Arabia and their geological framework. Arab. J. Sci. Eng. 1997, $22,3-31$.

6. Wagner, W. Groundwater in the Arab Middle East, 1st ed.; Springer: Berlin/Heidelberg, Germany, 2011.

7. Al Ajmi, H. Matrix versus fracture permeability in a regional sandstone aquifer (Wajid sandstone, SW Saudi Arabia). Grundwasser 2014, 19, 151-157. [CrossRef]

8. Piper, A.M. A graphic procedure in the geochemical interpretation of water-analyses. Trans. Am. Geophys. Union 1944, $25,914$. [CrossRef]

9. Datta, P.; Tyagi, S. Major ion chemistry of groundwater in Delhi area: Chemical weathering processes and groundwater flow regime. J. Geol. Soc. India 1996, 47, 179-188.

10. Moshrif, M.A.; El-Hiti, A. Lithofacies and petrography of Wajid sandstone (Cambrian-Ordovician) Saudi Arabia. J. Afr. Earth Sci. 1989, 9, 401-412. [CrossRef]

11. Babalola, L.O. Depositional Environments and Provenance of the Wajid Sandstone, Abha-Khamis Mushayt Area, Southwestern Saudi Arabia. Master's Thesis, King Fahd University of Petroleum and Minerals, Dhahran, Saudi Arabia, 1999.

12. Babalola, O.; Hussain, M.; Hariri, M. Origin of iron-rich beds in the basal Wajid Sandstone, Abha-Khamis Mushayt area, southwest Saudi Arabia. Arab. J. Sci. Eng. 2003, 28, 1-24.

13. Wanas, H.A.; Abdel-Maguid, N.M. Petrography and geochemistry of the Cambro-Ordovician Wajid Sandstone, southwest Saudi Arabia: Implications for provenance and tectonic setting. J. Asian Earth Sci. 2006, 27, 416-429. [CrossRef] 
14. Siddiqi, S.A.T.A. Depositional Environments and Facies Reservoir Properties of the Khusayyayan Member, Wajid Sandstone, Saudi Arabia. Master's Thesis, King Fahd University of Petroleum and Minerals, Dhahran, Saudi Arabia, 2007.

15. Mergany, M. Geological and Statistical Reservoir Characteristics of the Late Carboniferous-Permian Juwayl Member (Wajid Sandstone), Southwestern Saudi Arabia. Master's Thesis, King Fahd University of Petroleum and Minerals, Dhahran, Saudi Arabia, 2007.

16. Bassis, A.; Hinderer, M.; Meinhold, G. Petrography and geochemistry of Palaeozoic quartz-rich sandstones from Saudi Arabia: Implications for provenance and chemostratigraphy. Arab. J. Geosci. 2016, 9, 400. [CrossRef]

17. Benaafi, M.; Hariri, M.; Al-Shaibani, A.; Abdullatif, O.; Makkawi, M. Integrated geomechanical, petrographical and petrophysical study of the sandstones of the Wajid Group, SW Saudi Arabia. J. Afr. Earth Sci. 2018, 143, 162-177. [CrossRef]

18. Schoeller, H. Geochemistry of Groundwater. In Groundwater Studies-An International Guide for Research and Practice; UNESCO: Paris, France, 1977.

19. Schoeller, H. Qualitative Evaluation of Groundwater Resources. In Methods and Techniques of Groundwater Investigations and Development; United Nations Educational, Scientific and Cultural Organization (UNESCO): Paris, France, $1965 ;$ pp. $54-83$.

20. Parkhurst, D.L.; Appelo, C.A.J. Description of Input and Examples for Phreeqc Version 3: A Computer Program for Speciation, BatchReaction, One-Dimensional Transport, and Inverse Geochemical Calculations; US Geological Survey Publications: Austin, TX, USA, 2013.

21. Appelo, C.; Postma, D. Geochemistry Groundwater and Pollution, 2nd ed.; Balkema Publication: Rotterdam, The Netherlands, 2005.

22. Han, D.M.; Song, X.F.; Currell, M.J.; Yang, J.L.; Xiao, G.Q. Chemical and isotopic constraints on evolution of groundwater salinization in the coastal plain aquifer of Laizhou Bay, China. J. Hydrol. 2014, 508, 12-27. [CrossRef]

23. Mook, W.G.; Rozanski, K. Environmental Isotopes in the Hydrological Cycle: Principles and Applications; International Atomic Energy Agency: Vienna, Austria; UNESCO: Paris, France, 2000.

24. Michelsen, N.; Reshid, M.; Siebert, C.; Schulz, S.; Knöller, K.; Weise, S.; Rausch, R.; Al-Saud, M.; Schüth, C. Isotopic and chemical composition of precipitation in Riyadh, Saudi Arabia. Chem. Geol. 2015, 5, 413. [CrossRef]

25. Zeeb, C.; Göckus, D.; Bons, P.; Al Ajmi, H.; Rausch, R.; Blum, P. Fracture flow modelling based on satellite images of the Wajid Sandstone, Saudi Arabia. Hydrogeol. J. 2010, 18, 1699-1712. [CrossRef]

26. Benaafi, M.; Hariri, M.; Abdullatif, O.; Makkawi, M.; Al-Shaibani, A. Analysis of lineaments within the Wajid Group, SW Saudi Arabia, and their tectonic significance. Arab. J. Geosci. 2017, 10. [CrossRef] 